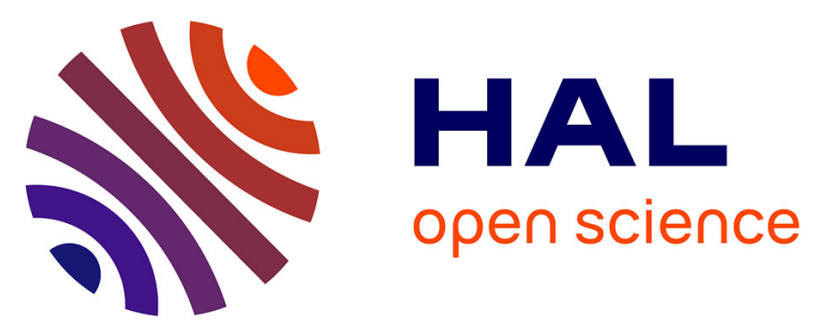

\title{
Metal-ion induced FRET in macrocyclic dynamic tweezers
}

Stéphanie Delbaere, Elena V. Tulyakova, Emilie Marmois, Gediminas

Jonusauskas, Elena N. Gulakova, Yuri V. Fedorov, Olga A. Fedorova

\section{To cite this version:}

Stéphanie Delbaere, Elena V. Tulyakova, Emilie Marmois, Gediminas Jonusauskas, Elena N. Gulakova, et al.. Metal-ion induced FRET in macrocyclic dynamic tweezers. Tetrahedron, 2013, 69 (38), pp.81788185. 10.1016/j.tet.2013.07.042 . hal-00874421

\section{HAL Id: hal-00874421 \\ https://hal.science/hal-00874421}

Submitted on 5 Mar 2018

HAL is a multi-disciplinary open access archive for the deposit and dissemination of scientific research documents, whether they are published or not. The documents may come from teaching and research institutions in France or abroad, or from public or private research centers.
L'archive ouverte pluridisciplinaire HAL, est destinée au dépôt et à la diffusion de documents scientifiques de niveau recherche, publiés ou non, émanant des établissements d'enseignement et de recherche français ou étrangers, des laboratoires publics ou privés.

\section{다)(1) $(5$}

Distributed under a Creative Commons Attribution - NonCommerciall 4.0 International 


\title{
Metal-ion induced FRET in macrocyclic dynamic tweezers
}

\author{
Stephanie Delbaere ${ }^{a}$, Elena V. Tulyakova ${ }^{a}$, Emilie Marmois ${ }^{b}$, Gediminas Jonusauskas ${ }^{b}$, \\ Elena N. Gulakova ${ }^{\mathrm{c}}$, Yuri V. Fedorov ${ }^{\mathrm{c}}$, Olga A. Fedorova ${ }^{\mathrm{c}, *}$ \\ ${ }^{a}$ Université Lille Nord de France, CNRS UMR 8516, UDSL, 3 rue du Professeur Laguesse BP83, F-59006 Lille, France \\ ${ }^{\mathrm{b}}$ Laboratoire Ondes et Matière d'Aquitaine (LOMA), UMR 5798, Université Bordeaux 1, 351, Cours de la Libération, 33405 Talence, France \\ ${ }^{c}$ A.N. Nesmeyanov Institute of Organoelement Compounds, 28 Vavilova street, 119991 Moscow, Russian Federation
}

\section{A R T I C L E I N F O}

\section{Keywords:}

Bis(styryl) dyes

Crown ether

Complex formation

FRET

Sandwich complex

Binding constants determination

\begin{abstract}
A B S T R A C T
We report here about effective FRET process (73 99\%) in mono $\mathrm{Mg}^{2+}$ complexes of symmetrical crown ether bis(styryl) dyes. The FRET process has not been observed in the free state and in binuclear com plexes. The formation of mononuclear complex provides two styrylic fragments with appropriate posi tions of absorption and emission bands for FRET. The other important parameter for FRET is the proper geometric orientation of both chromophores, which attain sandwich conformation with close posi tioning of complexed and free styryl fragments induced by ion modulated geometry reorganization of the bis dye.
\end{abstract}

\section{Introduction}

Traditionally, fluorescence resonance energy transfer (FRET) has been used to investigate the static and dynamics of the confor mational changes of macromolecules by attaching fluorophores at specific sites. ${ }^{1,2}$ It has led to invaluable information on biological systems involving nucleic acids, ${ }^{3}$ proteins, ${ }^{4}$ membranes, ${ }^{5}$ and car bohydrates. ${ }^{6}$ The recent interest in triggered molecular motion and molecular machines ${ }^{7,8}$ has led to extensive work on conformational control and change ${ }^{9}$ in artificial molecular systems, and mirrors the importance of such processes in the biological world.

The preparation of chromophore-quencher assemblies for such studies requires a suitable way to hold both components properly oriented and close enough together thus ensuring their efficient interaction. Commonly, this is achieved by use of a bridging covalent spacer between two sites. Alternatively, non covalent interactions such as hydrogen bonding or aromatic stacking (or often a combination of several interactions) can be used to control association of the chromophore and quencher, following the 'supramolecular' methods that are employed in natural photosynthesis. ${ }^{10} 14$

\footnotetext{
* Corresponding author. Tel.: +7 49913592 80; fax: +7 49913576 01; e-mail addresses: fedorova@ineos.ac.ru, fedorova@petrol.chem.msu.ru (O.A. Fedorova).
}

There are known examples of fluorescence chemosensors, which utilize photophysical changes produced by cation binding to initiate FRET. ${ }^{15,16}$ The FRET is known to be sensitive, selective, and able to adapt to a large variety of systems. ${ }^{16}$ However, reports on FRET based metal ion sensors are still scarce. ${ }^{17}$

It is known that FRET arises from an interaction between a pair of two different fluorophores., ${ }^{1,2}$ The FRET is required to have a certain extent of spectral overlap between the emission spectrum of the donor and the absorption spectrum of the acceptor. In pursuit of metal cation induced FRET, we have used crown containing bistyryl dyes of symmetrical structure (dyes 1-4, Scheme 1). In our research, we applied identical structural styryl units to elaborate macrocyclic dynamic tweezers. ${ }^{18} 20$ Dynamic molecular tweezers rely on the high degree of control of the distance and orientation of chromophores composed by an energy donor and an energy acceptor. Such parameters are critical for FRET, and we re port here an investigation of the crown containing styryl system as a scaffold supporting FRET and allowing ion induced FRET control. To the best of our knowledge, this is the first report where FRET is observed between two identical chromophore moieties in the presence of metal ions. The obvious advantages of the studied systems are easier synthesis of the bischromophore compounds when two chromophore fragments are identical, and that the FRET response in the crown containing bis dye compounds could be selective toward the particular metal ions. 

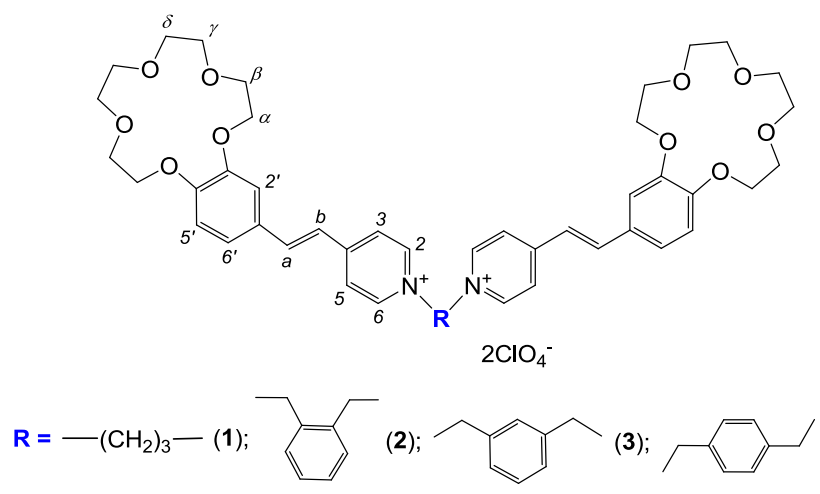

(4)

Scheme 1. Structures of the studied compounds.

\section{Results and discussion}

The designed FRET devices investigated here are composed of two identical 15 crown 5 styrylpyridines connected by isomeric xylenes or propylene spacers 1-4 (Scheme 1). The synthetic pro cedure as well as physical-chemical studies has been previously presented. ${ }^{20}$

\subsection{Complex formation}

The addition of $\mathrm{Mg}^{2+}$ perchlorate to the acetonitrile solution of crown containing bis(styryl)dyes $\mathbf{1 - 4}$ results in substantial hyp sochromic shifts of the long wavelength absorption bands (Fig. 1 shows the spectral changes for dye 1, the observed changes for 2-4 are presented in Table 1). This observation indicates that the metal cation interacts with crown ether moieties of dye. ${ }^{18,20}$ To determine the complexation stoichiometry and to estimate the stability of complexes, sets of the absorption curves obtained by variation of concentration of metal cations in acetonitrile solution of dyes were analyzed by SPECFIT program. ${ }^{21}$ The stability con stants and the position of maxima for complexes $\mathrm{L} \cdot \mathrm{M}$ and $\mathrm{L} \cdot \mathrm{M}_{2}$ are listed in Table 1.

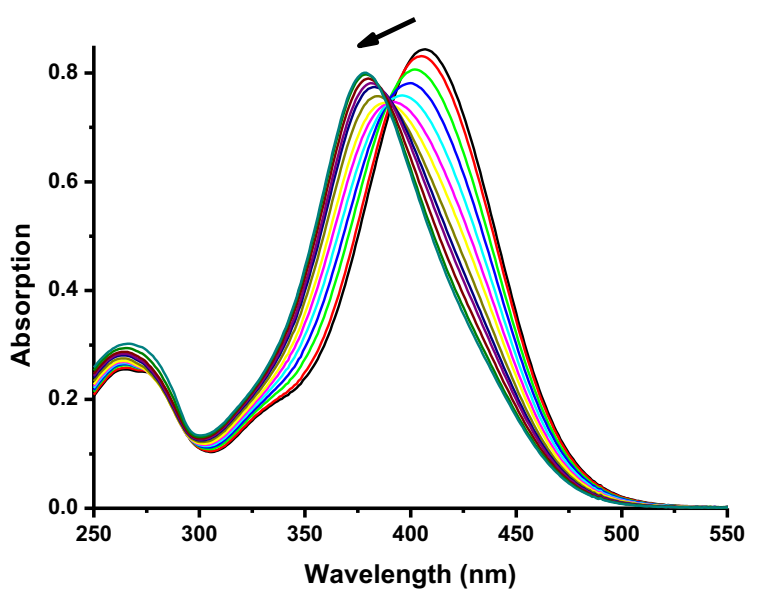

Fig. 1. Variation of the $1.5 \times 10{ }^{5} \mathrm{M}$ dye 1 electronic absorption spectra with increasing $\left[\mathrm{Mg}\left(\mathrm{ClO}_{4}\right)_{2}\right]$ in acetonitrile $\left(C_{\mathrm{M}} / C_{\mathrm{L}} \quad 0 \quad 50\right)$.

The absorption spectra of the complexes $\left(\mathrm{L} \cdot \mathrm{Mg}^{2+}\right)$ contain the band at 389-392 $\mathrm{nm}$ hypsochromically shifted relative to the free ligands (407-409 nm, Table 1). The absorption spectrum of mon ocomplexed dyes 1-4 can be readily fitted by a sum of spectral shapes of almost equal intensities of free ligand $\mathbf{4}$ and dou bly-complexed compounds (369-376 nm, Table 1, Fig. 2).
Table 1

Steady state absorption and complexation properties

\begin{tabular}{|c|c|c|c|c|c|c|}
\hline & $\begin{array}{l}\lambda_{\mathrm{abs}} \\
(\mathrm{nm})\end{array}$ & $\begin{array}{l}\varepsilon\left(1 \mathrm{~mol}^{1}\right. \\
\left.\mathrm{cm}^{1}\right) \times 10^{4}\end{array}$ & $\log K$ & $\begin{array}{l}\lambda_{\text {fluo }} \\
(\mathrm{nm})\end{array}$ & $\begin{array}{l}\Phi_{\text {fluo }} \\
(\%)\end{array}$ & $\begin{array}{l}\tau_{\text {fluo }} \\
\text { (ps) }\end{array}$ \\
\hline 1 & 409 & 5.62 & & 567 & 2.75 & $186 / 348$ \\
\hline $1 \mathrm{Mg}^{2+}$ & 390 & 4.45 & $\begin{array}{l}3.72 \pm 0.04 \\
4.8 \pm 0.03^{a}\end{array}$ & 567 & 1.76 & $159 / 367$ \\
\hline $1\left(\mathrm{Mg}^{2+}\right)_{2}$ & 374 & 5.33 & $\begin{array}{l}6.23 \pm 0.15 \\
7.8 \pm 0.2^{\mathrm{a}}\end{array}$ & 483 & 2.17 & 68 \\
\hline 2 & 407 & 5.35 & & 573 & 1.19 & $245 / 550$ \\
\hline $2 \mathrm{Mg}^{2+}$ & 392 & 4.77 & $4.56 \pm 0.01$ & 573 & 0.87 & $190 / 510$ \\
\hline $2\left(\mathrm{Mg}^{2+}\right)_{2}$ & 376 & 5.28 & $6.44 \pm 0.07$ & 487 & 2.37 & 70 \\
\hline 3 & 407 & 6.83 & & 569 & 3.56 & $228 / 450$ \\
\hline $3 \mathrm{Mg}^{2+}$ & 391 & 5.81 & $\begin{array}{l}4.77 \pm 0.03 \\
4.6 \pm 0.1^{\mathrm{a}}\end{array}$ & 569 & 1.92 & $119 / 434$ \\
\hline $3\left(\mathrm{Mg}^{2+}\right)_{2}$ & 368 & 6.43 & $\begin{array}{l}8.25 \pm 0.12 \\
8.2 \pm 0.2^{\mathrm{a}}\end{array}$ & 487 & 1.85 & 68 \\
\hline 4 & 408 & 5.74 & & 569 & 6.38 & $247 / 478$ \\
\hline $4 \mathrm{Mg}^{2+}$ & 389 & 4.66 & $\begin{array}{l}3.82 \pm 0.05 \\
3.8 \pm 0.1^{\mathrm{a}}\end{array}$ & 569 & 6.06 & $223 / 516$ \\
\hline $4\left(\mathrm{Mg}^{2+}\right)_{2}$ & 369 & 6.28 & $\begin{array}{l}7.71 \pm 0.03 \\
7.5 \pm 0.2^{\mathrm{a}}\end{array}$ & 484 & 2.73 & 75 \\
\hline
\end{tabular}

a Binding constants of the bis(styryl) dye series with magnesium(II) obtained by NMR titration method.

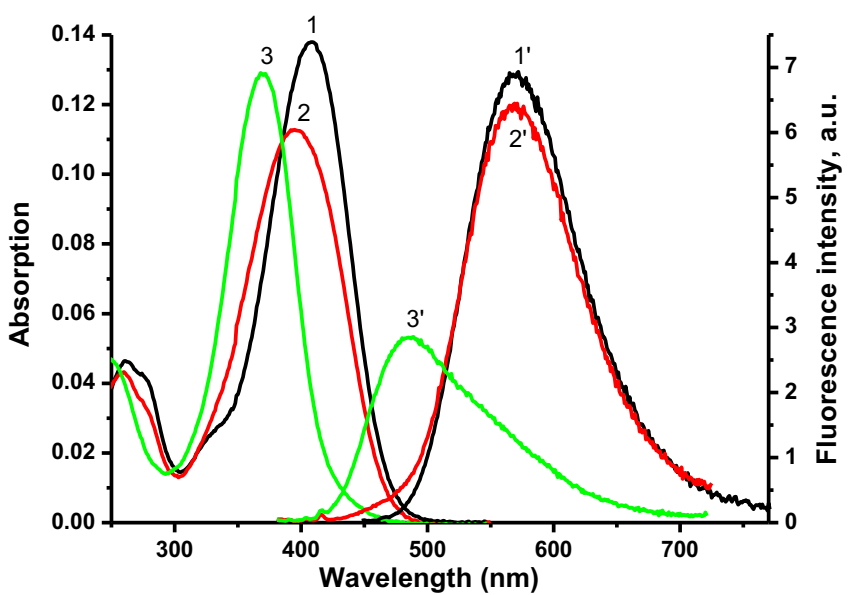

Fig. 2. Steady state absorption $(1,2,3)$ and emission spectra $\left(1^{\prime}, 2^{\prime}, 3^{\prime}\right)$ for compound 4 $\left(1,1^{\prime}\right)$ and its mono- $\left(2,2^{\prime}\right)$ and bi-complexes $\left(3,3^{\prime}\right)$ with $\mathrm{Mg}^{2+}$.

\subsection{Analysis of energy transfer efficiency}

According to the data in Table 1 and Fig. 2, emission of free dyes 1-4 is located at $567-569 \mathrm{~nm}$, for double complexed $\left[\mathrm{L} \cdot\left(\mathrm{Mg}^{2+}\right)_{2}\right]$ dyes $\mathbf{1}-\mathbf{4}$, the emission at $483-487 \mathrm{~nm}$ was found. On the contrary, the fluorescence spectra of monocomplexed dyes 1-4 are mainly composed from the spectrum of non complexed dyes. The analysis of steady state absorption suggested that both chromophores, which compose bis(styryl)dyes are absorbing light independently one from another like two independent molecules and also independently from crown occupation by cation. Yet the emission occurs always from the chromophore possessing the lower HOMO-LUMO gap. We can thus conclude that an energy transfer process occurs in monocomplexed compounds. So, as propyl and ortho , meta , para xylene spacers work as insulators and do not allow the electron exchange, we can suppose that Coulombic interaction is the dominant energy transfer process. After light was absorbed, the complexed part of the molecule (higher HOMO-LUMO energy gap) can transfer energy to the 
non complexed part of the molecule (lower energy gap). This energy transfer reduces the fluorescence intensity of complexed chromophore and increases the fluorescence intensity of non complexed part of the dye. Thus, the monomagnesium complexes of dyes 1-4 can act as donor of energy transfer in FRET systems, because FRET consists in the light induced excitation of the en ergy donor in a domain where the acceptor does not absorb, fol lowed by energy transfer from the donor to the acceptor, and finally emission from the acceptor (Scheme 2).

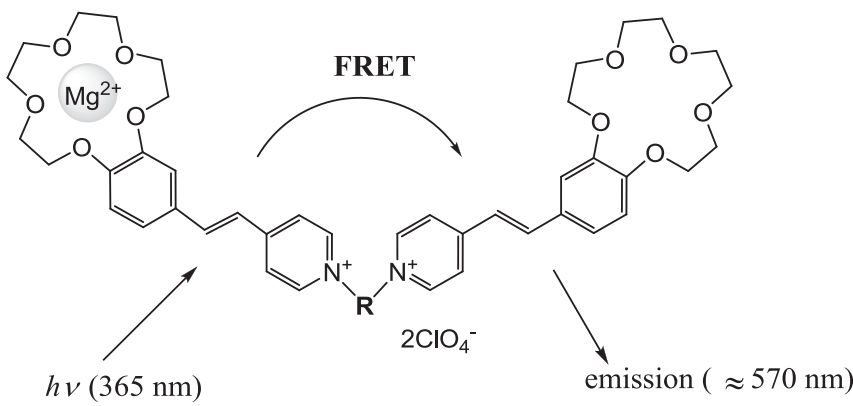

Scheme 2. Scheme of the energy transfer in monomagnesium complex.

In order to determine the energy transfer efficiency, first we need to deconvolute the experimental steady state absorption spectra of monocomplexed dyes $\mathbf{1}-\mathbf{4}$ to the spectra of bicomplexed dyes and the ones of non complexed dyes. As the steady state ab sorption bands of complexed and non complexed dyes are over lapping, it is necessary to deconvolute absorption into complexed and non complexed parts in order to correct fluorescence quantum yields with respect to real absorption of energy donor. In the case of compound 4 , only $44.5 \%$ of sample absorption was used to excite the complexed part of dye, thus a correction to overall energy transfer efficiency obtained only from fluorescence data should be more than twice (Fig. 3a). Then, the ratio of the integral fluores cence of monocomplexed blue shifted component to the integral of fluorescence of bicomplexed dye will serve for calculation of energy transfer efficiency (Fig. 3b). Accounting for all these parameters, the lower limit of the energy transfer efficiency in monocomplexed dyes are as high as $\mathbf{9 7 . 4 \%}$ for dye $\mathbf{1}, \mathbf{9 9}$.2\% for dye $\mathbf{2}, \mathbf{9 6 . 9 \%}$ for dye $\mathbf{3}$, and $73 \%$ in the case of dye 4 .

\subsection{Conformational analysis of macrocyclic bis(styryl) dyes series and their magnesium(II) complexes by NMR spectroscopy}

One of the critical parameters for FRET is appropriate geometric orientation of the chromophores in order to maximize the favorable interaction between the transition moments of donor emission and acceptor absorption. As indicated above, in all macrocyclic bis( styryl) dye complexes with magnesium(II) on a nominal 1:1 ratio, the photoexcitation results in a highly efficient intramolecular energy transfer process due to the favorable HOMO-LUMO energy gap difference between uncomplexed and complexed units. We expect to gain better insight into this process through conforma tional analysis and investigation of specific host dyes arrangement upon magnesium(II) binding. The conformational analysis was carried out by $1 \mathrm{D}$ and 2D NMR spectroscopy $\left({ }^{1} \mathrm{H},{ }^{13} \mathrm{C},{ }^{1} \mathrm{H}-{ }^{1} \mathrm{H}\right.$ COSY, ${ }^{1} \mathrm{H}-{ }^{13} \mathrm{C}$ HSQC, ${ }^{1} \mathrm{H}-{ }^{13} \mathrm{C} \mathrm{HMBC}$ ) (see Supplementary data) in $\mathrm{CD}_{3} \mathrm{CN}$. The respective positions in the two entities of all bis(styryl) dyes are chemically equivalent as only one type of proton signals is observed (Figs. 4a 1, Fig. 5a 4). This is in accordance with the rotation around the single bonds connecting the chromophores to the spacer teth ering two styryl units and fast rotation around one or two single bonds in $\mathrm{C}-\mathrm{C}=\mathrm{C}-\mathrm{C}$ fragment, thus leading to a $C_{2 v}$ symmetric av erage of all ligands on the NMR time scale (Scheme 1 ). Moreover, the magnitude of the coupling constant between $\mathrm{H} a$ and $\mathrm{H} b$ for all macrocyclic bis(styryl) dyes is equal to $16.0-16.2 \mathrm{~Hz}$. Due to the partial character of the double bond and considering the Karplus equations, the ${ }^{3} \mathrm{~J}$ value corresponds to a transoid coupling (dihedral angle $\left.180^{\circ}\right) .^{22}$

To further investigate the binding process of all bis(styryl) dyes, ${ }^{1} \mathrm{H}$ NMR titrations were performed with magnesium perchlorate (see Supplementary data Tables S1-S4, Figs. S1-S34). The char acteristic ${ }^{1} \mathrm{H}$ NMR signals of the aromatic region during the titration of host molecules 1 and $\mathbf{4}$ with magnesium(II) at the ratio 1:0, 1:1, and 1:2 are displayed in Figs. 4 and 5. Measuring the peak in tensities of the signals in free ligands and of new resonances that appear upon addition of magnesium(II) enables to plot the titration curves (Fig. 6) and to determine binding constants (Table 1).

The formation of magnesium(II) complexes with $\mathbf{1}$ and $\mathbf{4}$ in the ratio $1: 1$ is clearly indicated by the decrease of the initial family of dye signals and the appearance of new split resonances (Figs. 4b and $5 \mathrm{~b}$ ). The chemical shift changes are most pronounced for the methylene protons of the benzo 15 crown 5 ether located most closely to the complexed magnesium(II). As revealed in ${ }^{1} \mathrm{H}$ NMR
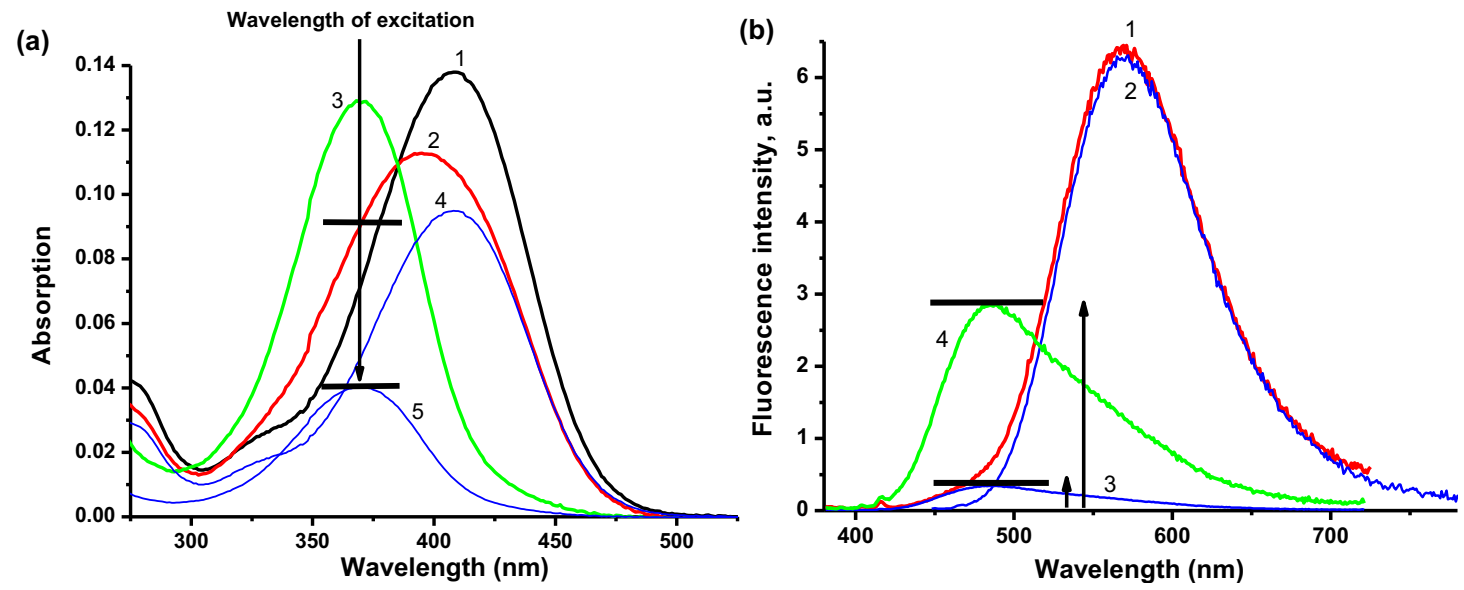

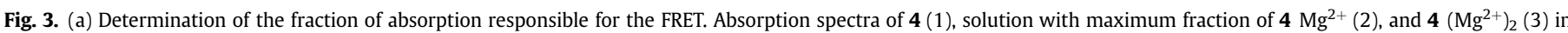

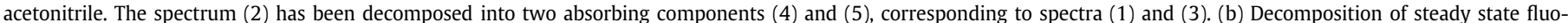
rescence spectrum of $\mathbf{4} \mathrm{Mg}^{2+}$ in acetonitrile (1) to the spectra of $\mathbf{4}(2)$ and $\mathbf{4}\left(\mathrm{Mg}^{2+}\right)_{2}(3)$. (4) Steady state fluorescence spectrum of $4\left(\mathrm{Mg}^{2+}\right)_{2}$ in acetonitrile. 


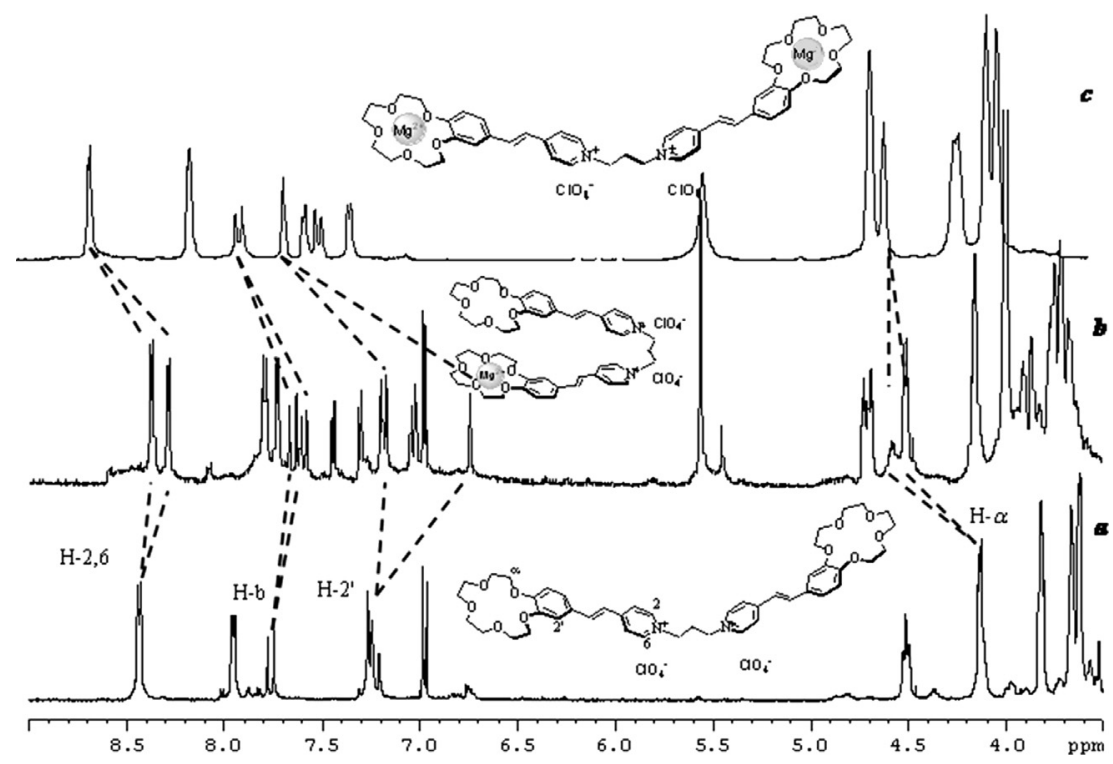

Fig. 4. ${ }^{1} \mathrm{H}$ NMR spectra of $\mathbf{1}(\mathrm{a}), \mathbf{1} \mathrm{Mg}^{2+}$ (b), $\mathbf{1}\left(\mathrm{Mg}^{2+}\right)_{2}$ (c) at $T 295 \mathrm{~K}$ in $\mathrm{CD}_{3} \mathrm{CN}$.

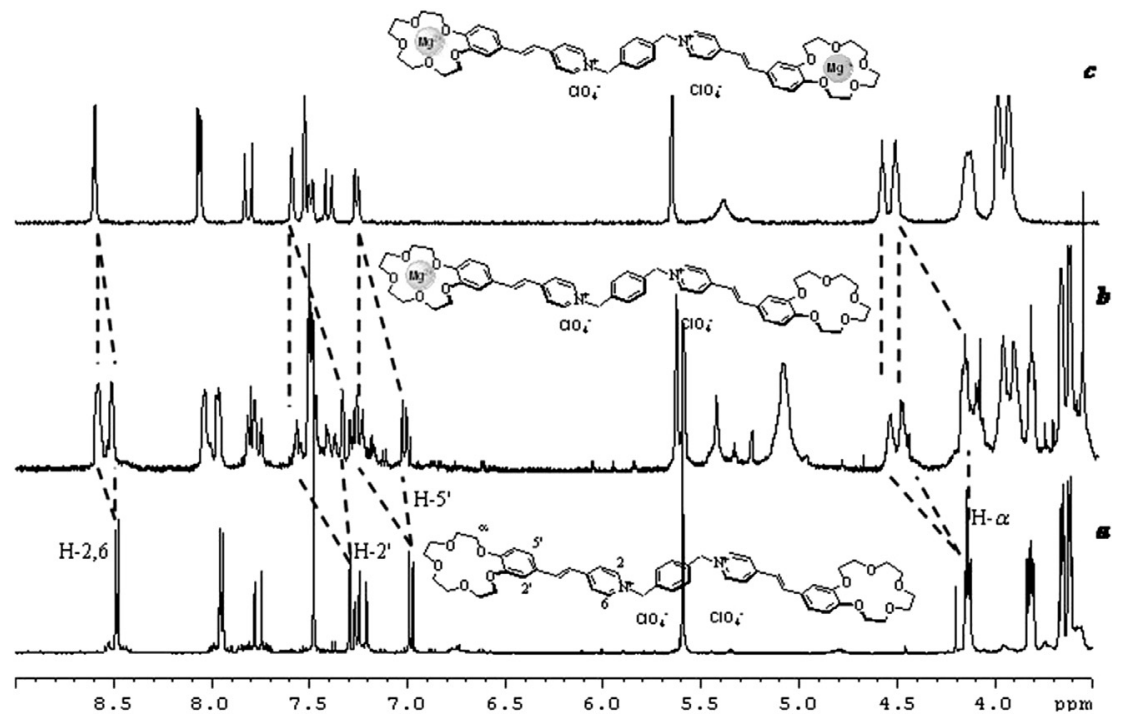

Fig. 5. ${ }^{1} \mathrm{H}$ NMR spectra of 4 (a), $4 \mathrm{Mg}^{2+}$ (b), $4\left(\mathrm{Mg}^{2+}\right)_{2}$ (c) at $T 295 \mathrm{~K}$ in $\mathrm{CD}_{3} \mathrm{CN}$.

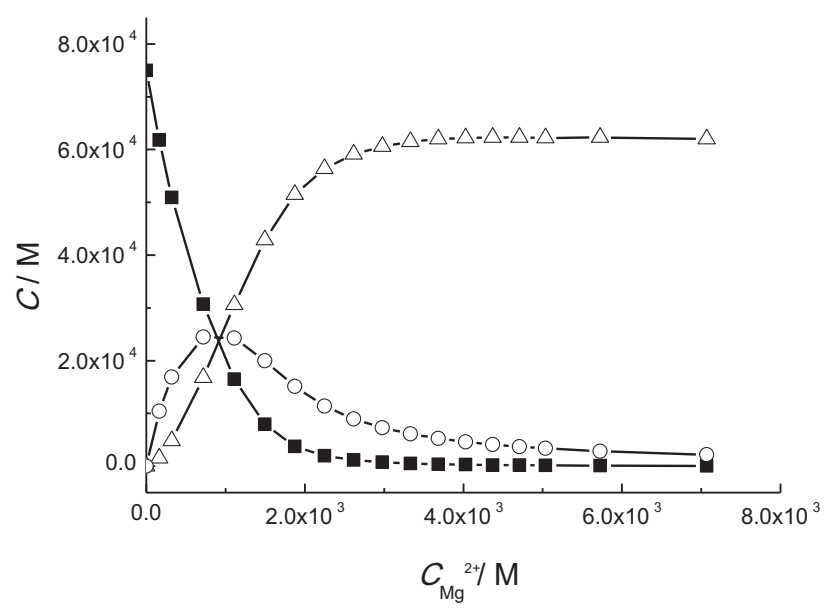

Fig. 6. Concentration profiles of the different species in the ${ }^{1} \mathrm{H}$ NMR titration experiment with 4 ( $C 0.75 \mathrm{mM}$ ) and $\mathrm{Mg}\left(\mathrm{ClO}_{4}\right)_{2}$ in acetonitrile- $d_{3}$ at $T 295 \mathrm{~K} ; 4$ (squares); $4 \mathrm{Mg}^{2+}$ (circles); $4\left(\mathrm{Mg}^{2+}\right)_{2}$ (triangles). spectra of series bis(styryl) macrocyclic dyes, the chemical equiv alence of the positions in the two parts of the molecule is lost upon complexation, since different chemical shifts are observed for the protons of uncomplexed and complexed entities. In case of $\mathbf{1}$, the shielding of all aromatic signals up to $\Delta \delta \quad 0.35 \mathrm{ppm}$ and the high field shift of the proton $\mathrm{H}^{\prime} \Delta \delta \quad 0.50 \mathrm{ppm}$ were observed. This shielding is typically a result of specific host reorganization assis tance of the uncomplexed part of the $\mathbf{1}$ in the binding process resulting in the formation of intramolecular asymmetric sandwich type structure. The bridge methylene protons $\mathrm{CH}_{2} \mathrm{Ph}$ show two sets of proton signals in the spectrum of $\mathbf{1}$ host, which indicates re stricted rotation about the methylene bridge between the spacer and chromophore units, and a different magnetic environment for each methylene proton in this rigidified structure. The same be havior was observed with $\mathbf{2}$ and $\mathbf{3}$ (Scheme 3 shows the structure of sandwich complex $\mathbf{3} \cdot \mathrm{Mg}^{2+}$ also typical for monomagnesium com plexes of dyes 1 and 3). ${ }^{18}$

However, in the case of magnesium(II) complex with macrocy clic ligand $\mathbf{4}$ in the ratio 1:1, only a downfield shift of all proton resonances was observed, suggesting the absence of intramolecular 

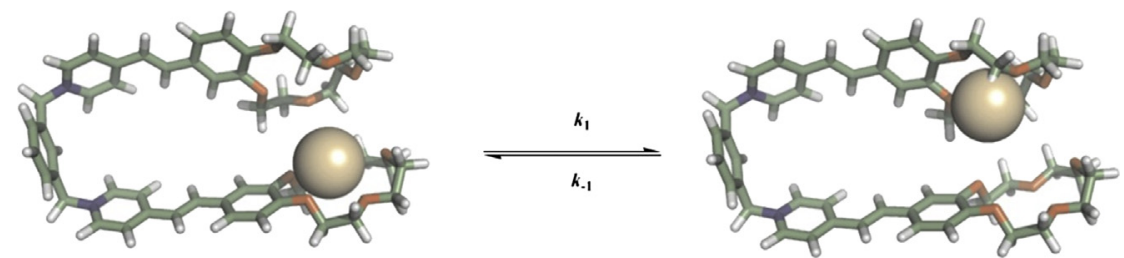

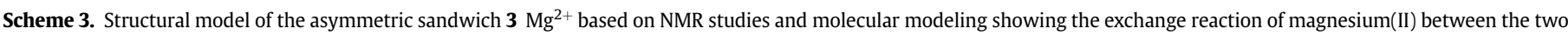
crown-ether units.

assistance (Fig. 5b). Furthermore, additional intermolecular ROEs were observed between protons $\mathrm{H} \alpha^{\prime}$ (free) and $\mathrm{H} 2^{\prime}$ (complexed), $\mathrm{H} \alpha^{\prime}$ (complexed) and $\mathrm{H} 2^{\prime}$ (free), $\mathrm{H} \alpha^{\prime}$ (free) and $\mathrm{H}^{\prime}$ (complexed), $\mathrm{H} \alpha^{\prime}$ (complexed) and $\mathrm{H} 2^{\prime}$ (free), $\mathrm{H} \gamma$ (complexed) and $\mathrm{H} \beta$ (free), $\mathrm{H} \alpha^{\prime}$ (complexed) and $\mathrm{H} \beta$ (free), $\mathrm{H} \beta$ (complexed) and $\mathrm{H} \gamma$ (free) demonstrating the intermolecular assistance of the second bis( styryl) dye molecule $\mathbf{4}$ in binding process as illustrated in Scheme 4. between the intramolecular sandwich as well as dimeric complexes $\mathbf{1} \cdot \mathrm{Mg}^{2+}$ and $\mathbf{3} \cdot \mathrm{Mg}^{2+}$ involving additional kinetic process of the di rect cation exchange between the two parts of host ligands.

Moreover, a large entropy gain upon host-guest complexation in 1:1 complexes $\mathbf{3} \cdot \mathrm{Mg}^{2+}$ and $\mathbf{1} \cdot \mathrm{Mg}^{2+}$ compared to $\mathbf{4} \cdot \mathrm{Mg}^{2+}$ is also pre dicted based both on relative contribution of cation and ligand des olvatation, and ligand conformational changes upon complexation. ${ }^{24}$

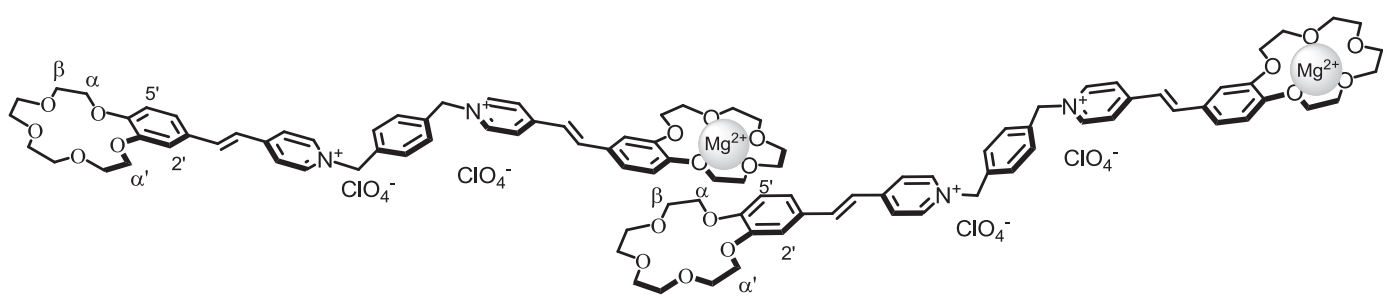

Scheme 4. Possible structures of magnesium complex of 4 .

Once the $1: 1$ ratio is exceeded by increasing the $\mathrm{Mg}^{2+}$ ion concentration, the signals of magnesium(II) complexes with 1, 2, 3 , 4 decrease in intensity and a third family of signals appears. The newly formed species are assigned to a 1:2 complex. This as sumption is supported by the significant downfield shift of all signals and their equivalence. The previous asymmetric sandwich conformers of 1, 2, 3 are destroyed leading to the reconstruction of a $C_{2 v}$ symmetric average geometry. Numerous dipolar correlations between $\mathrm{H} \mathrm{a} \leftrightarrow \mathrm{H} 2^{\prime}$ and $\mathrm{H} \mathrm{b} \leftrightarrow \mathrm{H} 2^{\prime}, \mathrm{H} \mathrm{a} \leftrightarrow \mathrm{H}^{\prime}$ and $\mathrm{H} \mathrm{b} \leftrightarrow \mathrm{H} 6^{\prime}, \mathrm{H}$ $\mathrm{a} \leftrightarrow \mathrm{H}$ 3,5 and $\mathrm{H} \mathrm{b} \leftrightarrow \mathrm{H}$ 3,5 found in ROESY spectra of 1:2 magne sium(II) complexes with all macrocyclic ligands 1, 2, 3, 4 indicate flexibility of structure and coexistence of several conformers. The values of binding constants obtained from ${ }^{1} \mathrm{H}$ NMR titration curves were found in a good agreement with the structures of host ligand. The lowest value of binding constant $K_{11}$ in the series of bis(styryl) tweezer ligands was deduced for $4 \cdot \mathrm{Mg}^{2+}$, where the intramolecular assistance of uncomplexed unit in the binding process is not pos sible due to the large distance between the two macrocyclic entities of the same molecule (see Table 1 ).

2.3.1. Determination of thermodynamic parameters. In order to un derstand the factors driving the molecular reorganization process in complexes of $\mathbf{1}, \mathbf{2}, \mathbf{3}, \mathbf{4}$ with magnesium(II) at a nominal 1:1 ratio, the standard thermodynamic parameters in acetonitrile have been de termined by measuring the temperature dependence of the binding constants. Well separated resonances were observed for the com plexes, pointing to sizable kinetic barrier for the exchange process, and allowing the determination of seven values of the binding constant $K$ between 233 and $293 \mathrm{~K}$ (Fig. 7). A van't Hoff plot of $\ln K$ versus $T^{-1}$ afforded values of the reaction enthalpies and entropies for the complex formation (Table 2). ${ }^{23}$ All three plots show that the binding process of the bis(styryl) dye series with metal cations is enthalpically disfavored and entropically favored. Whereas the first binding event of a magnesium cation to bis(styryl) dye $\mathbf{3}$ yields an enthalpy of about $19.8 \mathrm{~kJ} / \mathrm{mol}$, an enthalpy value for $\mathbf{1}$ is only $16.2 \mathrm{~kJ} /$ mol. This finding is in agreement with the structural differences

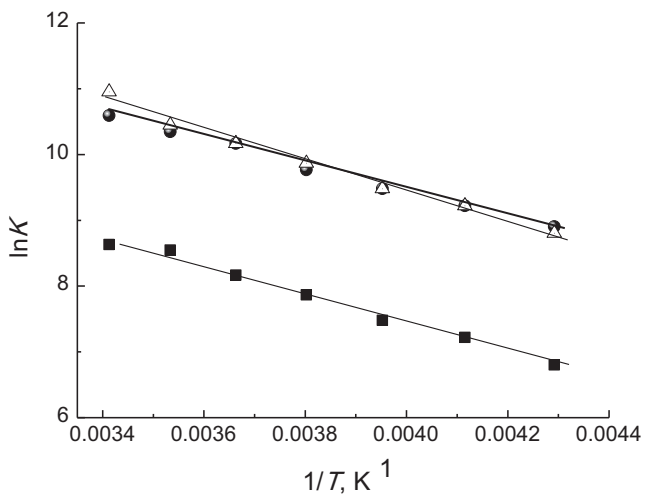

Fig. 7. A van't Hoff plot of $\mathbf{1} \mathrm{Mg}^{2+}$ (circles), $4 \mathrm{Mg}^{2+}$ (squares), $3 \mathrm{Mg}^{2+}$ (triangles).

Table 2

Activation parameters of the bis(styryl) dyes 1 complexes measured by ${ }^{1} \mathrm{H}$ NMR in acetonitrile- $d_{3}$

\begin{tabular}{lcl}
\hline Complex & $\Delta H\left(\mathrm{~kJ} \mathrm{~mol}^{1}\right)$ & $\Delta S\left(\mathrm{~J} \mathrm{~mol}^{1} \mathrm{~K}^{1}\right)$ \\
\hline $\mathbf{1} \mathrm{Mg}^{2+}$ & $16.2 \pm 0.5$ & $143.4 \pm 1.8$ \\
$\mathbf{2} \mathrm{Mg}^{2+}$ & $\mathrm{a}$ & \\
$\mathbf{4} \mathrm{Mg}^{2+}$ & $18.0 \pm 0.7$ & $133.6 \pm 2.6$ \\
$\mathbf{3} \mathrm{Mg}^{2+}$ & $19.8 \pm 0.9$ & $157.6 \pm 3.3$ \\
\hline
\end{tabular}

a Calculation of activation parameters was not possible due to low solubility of the initial complex.

\subsection{Exchange dynamics in the monomagnesium complexes measured by NMR spectroscopy}

2D EXSY NMR spectroscopy is an ideal technique for studying species that exchange slowly on the chemical shift time scale but exchange fast on the NMR relaxation time scale. This is also most useful for the investigation of supramolecular systems involved in complex dynamic processes. ${ }^{25,26}$ Thus, the $2 \mathrm{D}{ }^{1} \mathrm{H}-{ }^{1} \mathrm{H}$ EXSY 
(NOESY) spectra at a nominal 1:1 ratio of $\mathbf{1}, \mathbf{2}, \mathbf{3}, \mathbf{4}$ and magnesiu $\mathrm{m}(\mathrm{II})$ in $\mathrm{CD}_{3} \mathrm{CN}$ with a mixing time of $0.8 \mathrm{~s}$ at $295 \mathrm{~K}$ were measured. Fig. 8 illustrates a reasonable ligand exchange mechanism. The spectra clearly show correlation cross peaks of magnetization ex change between the uncomplexed and complexed part for mono magnesium complexes of all macrocyclic bis(styryl) dye molecules (Scheme 3).

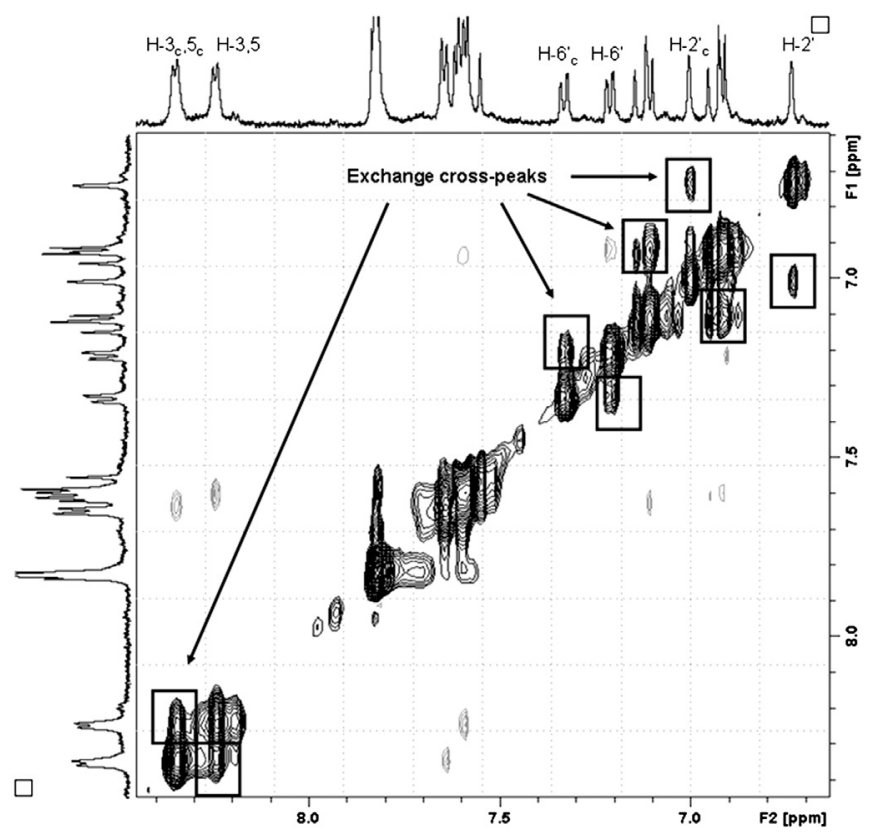

Fig. 8. A $2 \mathrm{D}{ }^{1} \mathrm{H} \quad{ }^{1} \mathrm{H}$ EXSY spectrum of $2 \mathrm{Mg}^{2+}$ (ratio $1: 1, \tau_{\mathrm{m}} 0.8 \mathrm{~s}$ ) showing ligand exchange between uncomplexed and complexed parts of 2 in $\mathrm{CD}_{3} \mathrm{CN}$ at $295 \mathrm{~K}$.

The life times and the activation energy values deduced from two dimensional exchange experiment are reported in Table 3. In general, smaller $\Delta G^{\neq}$values give larger exchange rates. The rigid and fixed spacer of covalently linked bis(styryl) dye host molecules may strongly affect the exchange rates and life time values $\left(k_{\mathrm{EX}} 1 / \tau\right)$. Thus, the asymmetric $\mathbf{3} \cdot \mathrm{Mg}^{2+}$ sandwich complex was the most $\mathrm{ki}$ netically stable complex, with a mean life time of $\tau 3.45 \mathrm{~s}$. The order of life time ( $m$ xylene $>0$ xylene $>$ propyl $>p$ xylene) correlates with the distance between uncomplexed and complexed units of the bis(styryl) macrocyclic dyes.

Table 3

Life times $(\tau)$, activation energies $\left(\Delta G^{\neq}\right)$of the exchange processes for series of bis(styryl) macrocyclic dyes magnesium(II) complexes in $\mathrm{CD}_{3} \mathrm{CN}$ at $295 \mathrm{~K}$

\begin{tabular}{lll}
\hline Compound & $\tau(\mathrm{s})$ & $\Delta G^{\neq}\left(\mathrm{kJ} \mathrm{mol}^{1}\right)$ \\
\hline $\mathbf{1} \mathrm{Mg}^{2+}$ & 0.45 & 70.3 \\
$\mathbf{2} \mathrm{Mg}^{2+}$ & 2.78 & 74.7 \\
$\mathbf{4} \mathrm{Mg}^{2+}$ & 0.39 & 70.1 \\
$\mathbf{3} \mathrm{Mg}^{2+}$ & 3.45 & 75.2 \\
\hline
\end{tabular}

Compared to $\mathbf{3} \cdot \mathrm{Mg}^{2+}$ with $m$ xylene spacer, ligand exchange was about 1.2 fold faster for asymmetric sandwich $\mathbf{2} \cdot \mathrm{Mg}^{2+}$ complex with o xylene spacer and over 7.6 fold faster for asymmetric sandwich $\mathbf{1} \cdot \mathrm{Mg}^{2+}$ where the two units are tethered by propyl chain. On the other hand, the exchange in $\mathbf{2} \cdot \mathrm{Mg}^{2+}$ complex was found to be the most effective process compared to exchange in $1 \cdot \mathrm{Mg}^{2+}$ system where the space restrictive intramolecular assistance of uncomplexed crown ether occurs.

\section{Conclusions}

The studies reported here show that the bis(styryl) dye scaffold decorated with crown ether substituents can be used to promote intramolecular FRET. In the free state, according to the NMR data, the structures of dyes 1-4 are linear.

In the present of magnesium(II) perchlorate in the ratio $1: 1$, dyes 1-3 tend to form the mononuclear species, characterized by an intramolecular sandwich conformation of the crown ether bearing styryl moieties. In case of compound $\mathbf{4}$, we proposed the formation of a $\mathrm{Mg}^{2+}$ complex possessing an intermolecular sandwich struc ture. Although sandwich complex formation is possible at low concentrations of magnesium cation, the presence of a large excess of the latter ends up with the binuclear complex with a totally opened conformation.

In the free state and in binuclear complexes, the FRET process has not been observed. Sandwich conformation of mono magnesium complex of 1-4 dyes favors energy transfer from the complexed part to uncomplexed one of bi(styryl) dye. The critical parameter for FRET to occur is spectral overlap between the electronic absorption of the acceptor and the emission of the donor. In the crown ether bis(styryl) dye, the formation of mononuclear complex provides two styrylic fragments with po sitions of absorption and emission bands appropriate for FRET. The other important parameter for FRET is the proper geometric ori entation of the chromophores, which attains a sandwich confor mation with closed position of complexed and free styryl fragments induced by ion modulated geometry reorganization of styryl fragments. Thus, this result shows that large amplitude movements of the lateral styryl substituents can be controlled by metal ion concentration in the solution, which leads in turn to an effective FRET process.

Similarly to biological systems where FRET can reveal the mu tual arrangement (and/or dynamics) of chromophoric fragments, our research on energy transfer gives insight on the disposition of styryl fragments in molecular tweezers. Thus in monocomplexes having sandwich structure, we observe the FRET and inversely in free and bis complexed dyes the FRET is absent.

The described dyes 1-4 can be considered as fluorescent sen sors for metal ions. By changing the composition of macrocyclic moiety, it is possible to vary the selectivity of dyes toward the particular metal ions and to observe the cation selective appear ance of fluorescence. Thus, the crown ethers show affinity for alkali and alkaline earth metals ions, thiacrown ethers can be used to selectively bind with $\mathrm{Hg}^{2+}, \mathrm{Ag}^{+}, \mathrm{Pb}^{2+}$, azacrown ether prefer to coordinate transition and heavy metal ions. ${ }^{27} 29$

\section{Experimental section}

\subsection{Materials}

Solvents and reagents were obtained from commercial suppliers and were used without further purification. The bis(styryl) dyes 1-4 were prepared according to the literature known procedure. $^{20}$

\subsection{UV/vis absorption measurements}

The binding constants $K$ are described by the following equations:

$\mathrm{L}+\mathrm{M}^{n+} \stackrel{\text { K11 }}{\rightleftarrows} K_{11} \mathrm{LM}$

$\mathrm{L}+2 \mathrm{M}^{n+} \stackrel{\text { K12 }}{\rightleftarrows} K_{12} \mathrm{LM}_{2}$ 
UV-vis spectra were measured on a Cary 50 UV-vis spectro photometer in conventional fused silica cells of $10 \mathrm{~mm}$ pathlength. Stock solutions of each compound were prepared, and dilutions of these stock solutions were used for absorption measurements over a concentration range by taking into account the solubility and absorbance of the respective compound. The temperature was controlled with a single cell Pelletier element (Varian). The solvents for UV/vis absorption were of spectroscopic grade and were used as received. Titrations were performed as constant host titrations ( $0.05 \mathrm{mM}$ in acetonitrile) at $298 \mathrm{~K}$ by addition of $5-20 \mu \mathrm{L}$ aliquots of the magnesium perchlorate solution $(0.5 \mathrm{mM}$ in acetonitrile solu tion) using a microsyringe to a fused silica cuvettes containing $2.000 \mathrm{~mL}$ of host solution. UV-vis spectra were recorded after each addition. The binding constant and the stoichiometry were ob tained from the titration curve by fitting these changes using the nonlinear regression analysis program SPECFIT. ${ }^{21}$

\subsection{Fluorescence measurements}

The steady state fluorescence measurements were realized on FluoroLog (Jobin Yvon) spectrofluorimeter. All measured fluores cence spectra were corrected for the non uniformity of detector spectral sensitivity. The samples were placed in $1 \mathrm{~cm}$ fused silica cells. Rhodamine B in ethanol ( $\Phi_{\mathrm{fl}} \quad 0.49$ ) was used as fluorescence quantum yield standard. The corrections for the excitation ab sorption as well as the fluorescence absorption were realized using standard procedures.

\subsection{NMR experiments}

All NMR experiments were recorded on a Bruker Avance $500 \mathrm{MHz}$ spectrometer. The measurements were done using the $\mathrm{CD}_{3} \mathrm{CN}$ signal as internal reference (1.94 ppm at $\left.295 \mathrm{~K}\right){ }^{30}$

4.4.1. ${ }^{1} \mathrm{H}$ NMR titration experiments with the respective metal per chlorates. Aliquots of a metal perchlorate solution $(0.01-0.1 \mathrm{M}$ in $\mathrm{CD}_{3} \mathrm{CN}$ ) were added to a bis(styryl) tweezer solution $(0.8-1.0 \mathrm{mM}$ in $\mathrm{CD}_{3} \mathrm{CN}$ ) and ${ }^{1} \mathrm{H}$ NMR spectra were recorded after each addition. The quantities of the different species were calculated from the integrated areas of NMR signals.

4.4.2. Calculation of binding constants. We also calculated the sta bility constants of complexation between hosts and guest using ${ }^{1} \mathrm{H}$ NMR single point method. ${ }^{31}{ }^{33}$ As can be seen from Figs. 4 and 5 in the manuscript, chemical exchange is slow on the NMR time scale and peaks are observed for both complexed and uncomplexed species, so stability constants $K_{11}$ and $K_{12}$ could be determined by integration of complexed and uncomplexed unit of the bis(styryl) tweezer molecules.

4.4.3. $2 D$ EXSY experiments. The $2 \mathrm{D}$ EXSY spectra were recorded at $273 \mathrm{~K}$ on $500 \mathrm{MHz}$ Bruker spectrometer. The mixing time was $800 \mathrm{~ms}$. The rate constants $(k)$ were calculated employing the Eqs. $1-5$, in which $\tau_{\mathrm{m}}$ is mixing time, $I_{\mathrm{AB}}$ and $I_{\mathrm{BA}}$ are cross peak in tensities, $I_{\mathrm{AA}}$ and $I_{\mathrm{BB}}$ are diagonal peak intensities, and $X_{\mathrm{A}}, X_{\mathrm{B}}$ are molar fractions of the free component and complex, which were determined by ${ }^{1} \mathrm{H}$ NMR integration. ${ }^{25 e, 26 a}$

$$
A \underset{k_{1}}{\stackrel{k_{1}}{\rightleftarrows}} B
$$

$k \quad k_{1}+k_{-1}$

$r \quad 4 X_{\mathrm{A}} X_{\mathrm{B}} \frac{\left(I_{\mathrm{AA}}+I_{\mathrm{BB}}\right)}{\left(I_{\mathrm{AB}}+I_{\mathrm{BA}}\right)} \quad 2\left(X_{\mathrm{A}} \quad X_{\mathrm{B}}\right)$ $k \quad \frac{1}{\tau_{\mathrm{m}}} \ln \frac{r+1}{r \quad 1}$

$$
\Delta G^{\neq} \quad \mathrm{R} T \ln \frac{k h}{k_{\mathrm{B}} T}
$$

\section{Acknowledgements}

Financial support from the Centre National de la Recherche Scientifique (PICS N³904), University Bordeaux 1, Région Aqui taine and the CNRS Russian Foundation for Basic Research (grant project: 1003 93106) is greatly appreciated. Part of this collaborative work was realized within the framework GDRI CNRS 93 'Phenics' (Photoswitchable Organic Molecular Systems \& Devices).

\section{References and notes}

1. Lakowicz, J. R. Principles of Fluorescence Spectroscopy; Kluwer/Plenum: New York, NY, 1999.

2. Vander Meer, W. B.; Coker, I. G.; Chen, S.-Y. Resonance Energy Transfer, Theory and Data; VCH: Weinheim, Germany, 1994.

3. Klostermeier, D.; Millar, D. P. Biopolymers 2002, 67, 159179.

4. Meng, J.-J.; Rojas, M.; Bacon, W.; Stickney, J. T.; Ip, W. Methods Mol. Biol. 2005 289, 341358.

5. Parthasarathy, R.; Groves, J. T. Cell Biochem. Biophys. 2004, 41, 391414.

6. Rice, K. G.; Kevin, G. Anal. Biochem. 2001, 297, 117122.

7. Balzani, V.; Credi, A.; Raymo, F. M.; Stoddart, J. F. Angew. Chem., Int. Ed. 2000, 39 33483391.

8. Balzani, V.; Venturi, M.; Credi, A. Molecular Devices and Machines: A Journey into the Nanoworld; Wiley-VCH: Weinheim, Germany, 2003.

9. Molecular Machines and Motors: Series: Structural \& Bonding; Sauvage, J.-P., Ed.; Springer: Berlin, Germany, 2001; Vol. 99; p. 302.

10. Amendola, V.; Fabbrizzi, L.; Mangano, C.; Pallavicini, P. Acc. Chem. Res. 2001, 34, 488493.

11. Fabbrizzi, L.; Poggi, A. Chem. Soc. Rev. 1995, 24, 197202.

12. de Silva, A. P.; Gunaratne, H. Q. N.; Gunnlaugsson, T.; Huxley, A. J. M.; McCoy, C. P.; Rademacher, J. T.; Rice, T. E. Chem. Rev. 1997, 97, 15151566.

13. Bergonzi, R.; Fabbrizzi, L.; Licchelli, M.; Mangano, C. Coord. Chem. Rev. 1998, 170 3146.

14. Watrob, H. M.; Pan, C. P.; Barkley, M. D. J. Am. Chem. Soc. 2003, 125, 73367343. 15. Hecht, S.; Vladimirov, N.; Frechet, J. M. J. J. Am. Chem. Soc. 2001, 123, 1825.

16. Weiss, S. Science 1999, 283, 16761683.

17. (a) Lee, M. H.; Kim, H. J.; Yoon, S.; Park, N.; Kim, J. S. Org. Lett. 2008, 10, 213 216; (b) Lee, M. H.; Quang, D. T.; Jung, H. S.; Yoon, J.; Lee, C.-H.; Ki, J. S. J. Org. Chem. 2007, 72, 4242 4245; (c) Kar, C.; Adhikari, M. D.; Ramesh, A.; Das, G. Inorg. Chem. 2013, 52, 743 752; (d) Neupane, L. N.; Park, J.-Y.; Park, J. H.; Lee, K.-H Org. Lett. 2013, 15, 254 257; (e) Zhang, J. F.; Zhou, Y.; Yoon, J.; Kim, Y.; Kim, S. J.; Kim, J. S. Org. Lett. 2010, 12, 38523855.

18. Tulyakova, E. V.; Vermeersch, G.; Gulakova, E. N.; Fedorova, O. A.; Fedorov, Yu. V.; Micheau, J.-C.; Delbaere, S. Chem. Eur. J. 2010, 16, 56615671.

19. Gromov, S.; Fedorova, O.; Ushakov, E.; Buevich, A.; Baskin, I.; Pershina, Y.; Eliasson, B.; Edlund, U.; Alfimov, M. J. Chem. Soc., Perkin Trans. 2 1999, 13231329

20. Fedorova, O. A.; Chernikova, E. Yu.; Fedorov, Y. V.; Gulakova, E. N.; Peregudov, A. S.; Lysenko, K. A.; Jonusauskas, G.; Isaacs, L. J. Phys. Chem. B 2009, 113 , 1014910158.

21. Gampp, H.; Maeder, M.; Meyer, C. J.; Zuberbuhler, A. D. Talanta 1985, 32 95109.

22. Karplus, M. J. Am. Chem. Soc. 1963, 85, 28702871.

23. (a) Kusukawa, T.; Yoshizawa, M.; Fujita, M. Angew. Chem., Int. Ed. 2001, 40 1879 1884; (b) Pastor, A.; Martínez-Viviente, E. Coord. Chem. Rev. 2008, 252, 2314 2345; (c) Leung, D. H.; Bergman, R. G.; Raymond, K. N. J. Am. Chem. Soc 2008, 130, 2798 2805; (d) Parac, T. N.; Caulder, D. L.; Raymond, K. N. J. Am Chem. Soc. 1998, 120, 8003 8004; (e) Leung, D. H.; Bergman, R. G.; Raymond, K. N. J. Am. Chem. Soc. 2006, 128, 9781 9797; (f) Haino, T.; Kobayashi, M.; Fukazawa, Y. Chem. Eur. J. 2006, 12, 33103319.

24. (a) Buschmann, H.-J.; Mutihac, R.-C. M.; Schollmeyer, E. J. Solution Chem. 2009 38, 209 217; (b) Izatt, R. M.; Pawlak, K.; Bradshaw, J. S.; Bruening, R. L. Chem. Rev. 1995, 95, 2529 2586; (c) Buschmann, H.-J. J. Solution Chem. 1988, 17, 277286.

25. (a) Perrin, C. L.; Dwyer, T. J. Chem. Rev. 1990, 90, 935 967; (b) Rudkevich, D. M. Hilmersson, G.; Rebek, J. J. Am. Chem. Soc. 1998, 120, 12216 12225; (c) Hof, F. Nuckolls, C.; Craig, S. L.; Martin, T.; Rebek, J., Jr. J. Am. Chem. Soc. 2000, 122, 
10991 10996; (d) Cai, M.; Sidorov, V.; Lam, Y.-F.; Flowers, R. A.; Davis, J. T. Org. Lett. 2000, 2, 1665 1668; (e) Pons, M.; Millet, O. Prog. Nucl. Magn. Reson. Spectrosc. 2001, 38, 267281.

26. (a) Nakazawa, J.; Sakae, Y.; Aida, M.; Naruta, Y. J. Org. Chem. 2007, 72, 9448 9455; (b) Chang, S.-Y.; Jang, H.-Y.; Jeong, K.-S. Chem. Eur. J. 2003, 9, 15351541.

27. Host Guest Complex Chemistry In Topics in Current Chemistry; Vogtle, F. Weber, E., Eds.; Springer: Berlin, Gemany, 1981; Vol. 98.

28. Sevdic, D.; Fesete, L.; Meider, H. J. Inorg. Nucl. Chem. 1980, 42, 885889.
29. (a) Fedorova, O.; Fedorov, Y.; Oshchepkov, M. J. Electroanal. 2012, 24, 1739 1744; (b) Fedorova, O.; Fedorov, Y.; Oshchepkov, M.; Dobrovolskaya, M. J. Phys. Org. Chem. 2012, 25, 835839.

30. Gottlieb, H. E.; Kotlyar, V.; Nudelman, A. J. Org. Chem. 1997, 62, 75127515

31. (a) Fielding, L. Tetrahedron 2000, 6151 6170; (b) Wacker, P.; Kleinpeter, E. J. Incl. Phenom. Macrocycl. Chem. 2007, 59, 331339.

32. Liu, Y.; Li, Ch.-J.; Zhang, H.-Y.; Wang, L.-H.; Luo, Q.; Wang, G. J. Chem. Phys. 2007, 126, 064705.

33. Botsi, A.; Perly, B.; Hadjoudis, E. J. Chem. Soc., Perkin Trans. 2 1997, 8994. 